\title{
The UpPer Tigris Region BetweEn Rome, Iran, AND ARMENIA*
}

\author{
Michał Marciak \\ iD http:/orcid.org/0000-0002-1263-222X \\ Jagiellonian University in Kraków
}

\begin{abstract}
The aim of this paper is to provide an overview of the geopolitical status of the Upper Tigris area in antiquity, with a special focus on the period between ca. $401 \mathrm{BCE}$ and the 6th century CE. Despite the popular impression that this area had a distinctly Armenian character, a closer look at its history shows that it was rather a territory with many local geopolitical entities that many neighboring countries periodically fought to possess. This area was strategically significant as a transit region located on the crossroads of important long-distance communication lines. Likewise, its natural resources were undoubtedly crucial to the neighboring countries. Indeed, powerful neighbors around the Upper Tigris area, including Armenia, the Iranian kingdoms of the Parthians and Sasanians, and Rome, sought to control this area, which was often located on the fringes of their states and as such was inevitably doomed to be contested by these empires on many occasions. This situation can be acutely seen in the conflict between Rome and the Iranian kingdoms of the Parthians and Sasanians, when northern Mesopotamia became a real battleground between the competing empires. In particular, the paper will sketch the development of the geopolitical status of several small geopolitical entities in this region-Sophene, Osrhoene, Gordyene, and Adiabene.
\end{abstract}

Keywords: Upper Tigris, Armenia, Rome, Parthians, Sophene, Osrhoene, Gordyene, Adiabene.

In the Hellenistic period, a number of small geopolitical entities in the Upper Tigris region (understood as stretching along the course of the Tigris from its source near Lake Hazar to its tributary, the Great Zab River in modern Kurdish Iraq) emerged onto the political scene and remained there until Late Antiquity, although often under various names and in different forms, playing varying roles throughout their history (see Map 1). Although some of them are frequently labeled as Armenian, Iranian (Parthian or Sasanian), or even Roman, a closer examination shows that the origin of these countries and their history cannot be fully understood through an unambiguous paradigm of one nation's heritage.

* Preparation of this paper was possible thanks to a grant from the De Brzezie Lanckoroński Foundation for a research visit to the British Library in London in 2018. 


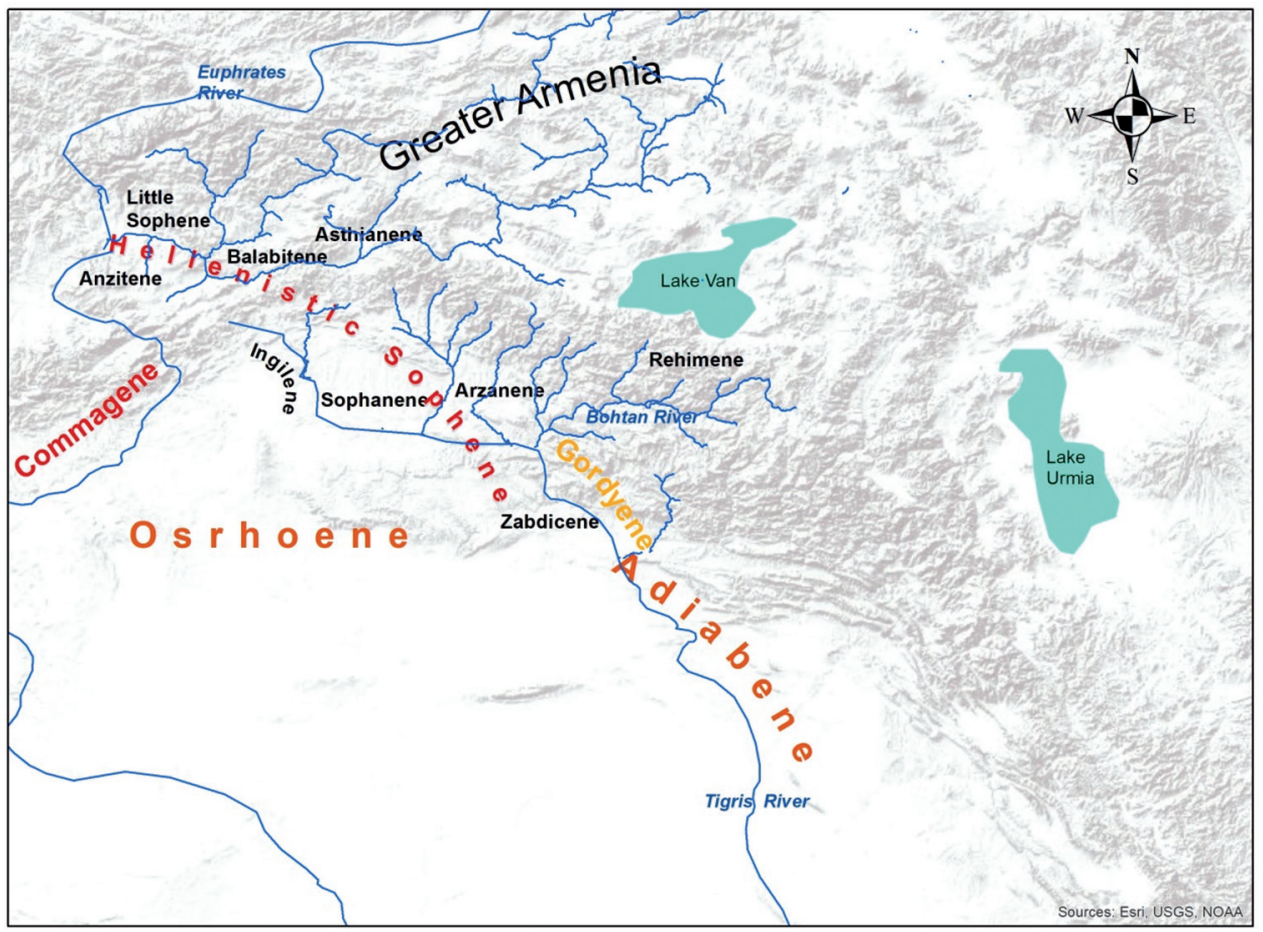

Map 1. Northern Mesopotamia in the Hellenistic and Parthian-Roman Times (by M. Marciak using ArcGIS 10)

It is on the occasion of the march of the Greek army of the "Ten Thousand" from Mesopotamia to the Black Sea in 401 BCE, described in Xenophon's Anabasis, that we first receive valuable clues about the administrative status of part of the Upper Tigris area shortly before the Hellenistic period. First, we learn that the land of the Karduchoi was located between the satrapy of Assyria and the satrapy of Armenia, and we also learn that its border with Armenia fell along the Kentrites River, which can easily be identified as the modern Bohtan River (Anab. 4.1.1-4.3.1). ${ }^{1}$ From this, it follows that whatever territory along the Tigris the Greeks passed by before crossing the Kentrites River did not belong to Armenia. This includes both the land of the Karduchoi (later known as Gordyene) and the area of the once Assyrian cities of Assur, Nimrud, and Nineveh, which later belonged to the Hellenistic kingdom of Adiabene. We also learn from Xenophon (Anabasis 4.4.4) that in $401 \mathrm{BCE}$, Tiribazos was satrap of Western Armenia and Orontes was satrap of (Eastern) Armenia. However, the precise route of the march of the Ten Thousand through Armenia has been a subject of prolonged controversy with two main options - a march north up the valley of the Bitlis River towards Lake Van and then to the Mus plain, or a march westwards through the Upper Tigris Valley for the Taurus pass north of Diyarbakır and northwest of Lice. ${ }^{2}$ If the latter route is correct

1 Marciak 2017, 163.

2 For an overview, see Comfort - Marciak 2018, 8-12. 
(as was recently suggested by A. Comfort and M. Marciak 2018), ${ }^{3}$ this would mean that much of the Upper Tigris Valley (approximately west of the Batman River) belonged to the satrapy of Western Armenia. This would certainly provide a good context for Sophene's expansion towards the Upper Tigris Valley in the Hellenistic period, although one should be warned against seeing it or later conquests as an ethnically motivated move because, as has long been recognized, the "tribal and linguistic multiplicity of the Armenian highlands is undeniable" in the Achaemenid period. ${ }^{4}$ Bluntly put, the aim of the Hellenistic conquests could not have been to "unite one people under one ruler" (P.Z. Bedoukian's statement about Tigranes the Great's conquests), ${ }^{5}$ since one people did not yet exist. The conquests should rather be perceived as one of the factors leading towards the dominance of Armenian tribes in the fragmented ethnic and linguistic mosaic of the Armenian highlands and the later occurrence of Armenian influence on parts of the Upper Tigris area.

There is no question that the political origin of small independent Hellenistic kingdoms in the Upper Tigris area was connected with macro-political developments in the Near East in the 3rd and 2nd centuries BCE. ${ }^{6}$ First and foremost, new kingdoms emerged onto the international scene in the context of a considerable political vacuum in the region: the Seleucid kingdom started to lose its influence over much of its territory in the East, but the Parthians/Arsacids had not yet managed to impose their rule in Mesopotamia. ${ }^{7}$ At the same time, another very important factor was the existence of specific local conditions leading to the emergence of local geopolitical entities. ${ }^{8}$ In the case of Sophene, it has been convincingly shown by Margherita Facella that the Hellenistic kingdom arose as a result of the partition of the territories of the Orontid dynasty into two separate lines around the middle of the 3rd century BC — one ruling in Sophene (first including Commagene) and another in Greater Armenia. ${ }^{9}$ In this context, Strabo, our main source (11.14.5), provides us with a long list of the original territory and new acquisitions by the kings of Sophene (Zariadres) and Greater Armenia (Artaxias). In the most general terms, Strabo's text is revealing for at least two reasons. ${ }^{10}$ First, it distinguishes between the original, apparently territorially modest, territories held by the two rulers and their new acquisitions. Second, Strabo sees some linguistic unity in his own times in the conquered territories as a result of Zariadres' and Artaxias' conquests. This in turn reflects a still very complex ethnic and linguistic situation in the early 2 nd century CE.

What, then, was the extent of the political territory of the kingdom of Sophene? Unfortunately, the identifications of the key toponyms in Strabo's text are highly problematic. ${ }^{11}$ Nevertheless, the general impression we get from the text is that the core of Hellenistic Sophene was located in the area matching the modern Dersim region

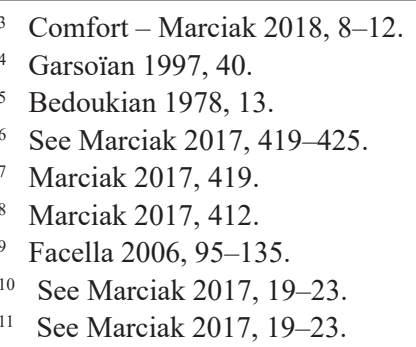


(occupying most of the Turkish Tunceli province), the lower Murat Valley (on both sides of the Murat River), and the Elazığ plain. ${ }^{12}$ This location in fact coincides with the center of the territory occupied by the pre-Hellenistic Suppani, who gave their name to these lands. ${ }^{13}$ As for Sophene's new acquisitions, Zariadres expanded its territory, especially eastwards in two directions: towards Greater Armenia and over the Taurus into the area of modern Diyarbakir and the Upper Tigris valley. ${ }^{14}$ However, Sophene's extension towards Greater Armenia culminated only during the reign of Zariadres, when Sophene probably extended as far as the mountains located to the east of Khorzene and Asthianene. ${ }^{15}$ After this successful but short period, long-term possessions of the kingdom of Sophene in this area were probably limited to only the lands of Balabitene and Asthianene along the Murat River. ${ }^{16}$ Sophene's expansion eastwards (over the Taurus) had more lasting consequences. Sophene's conquests included first the modern Diyarbakır region (located east of the Taurus at Ergani and west of the Dibene River), and next a considerable part of the Upper Tigris valley (stretching east of the Dibene River and west of the Batman River). ${ }^{17}$ Sophene's influence in this region also extended as far as the limestone hills, Tur Abdin, and the Mazi Mountains south of the Tigris. ${ }^{18}$ It should be emphasized that the acquisitions of Sophene southeast of the Taurus became closely integrated into Sophene as a cultural and geopolitical entity, which was later reflected in Roman, Byzantine, and Armenian sources. ${ }^{19}$

It was also in the Hellenistic period when two other kingdoms emerged on the international scene. In the case of Adiabene, ${ }^{20}$ next to the purely external factor of the disintegration of the Seleucid kingdom, it appears that the key domestic factor for the rise of this kingdom must have been both the long continuity of local administrative borders (probably determined by local geography) and the old tradition of local government in the urban centers of the once powerful empire of Assyria. ${ }^{21}$ It seems that the city of Arbela may not have experienced the same scale of demolition as the cities of Ashur and Nineveh during the final collapse of the Neo-Assyrian Empire, or at least it recovered considerably earlier than the other Neo-Assyrian cities. ${ }^{22}$ This situation apparently contributed to Arbela's significant role in the age of the development of new local geopolitical entities in Mesopotamia in the 3rd and 2nd centuries BCE. ${ }^{23}$ In this context, both a highly favorable macro-political situation and a prosperous agricultural environment must have contributed to the emergence of a key transregional geopolitical entity in northern Mesopotamia - the kingdom of Adiabene. ${ }^{24}$ The reign of Abdissar, the first

\footnotetext{
Marciak 2017, 53.

Marciak 2017, 53.

Marciak 2017, 54.

Marciak 2017, 54.

Marciak 2017, 54.

Marciak 2017, 54.

8 Marciak 2017, 54.

Marciak 2017, 54.

20 See Marciak 2017, 422-423.

21 Marciak 2017, 422.

22 Marciak 2017, 422.

23 Marciak 2017, 422.

24 Marciak 2017, 422.
} 
attested king of Adiabene, is known only through his coins, which have been dated to ca. 164 BCE solely on stylistic grounds. ${ }^{25}$ Although very little is known about the origin of the kingdom of Gordyene (the first king, Zarbienos, is attested in ancient sources only in $71 / 70 \mathrm{BCE}){ }^{26}$ it appears that this kingdom had a strong ethnic background: the economically self-sufficient and warlike mountainous tribe of the Karduchoi expanded their control beyond its natural borders in the mountains south of the Bohtan River and subjugated the natural sway of the Upper Tigris valley, approximately between the modern Batman and Khabur rivers. ${ }^{27}$ Perhaps the establishment of the kingdom of Gordyene took place in the latest phase of the Seleucid disintegration in Mesopotamia (e.g., $140-122 / 121 \mathrm{BCE}){ }^{28}$

With the coming of Parthian dominance in the region, both Greater Armenia and small geopolitical entities in the Upper Tigris area lost their independence, but not necessarily their royal status, since they became part of the Parthian Commonwealth, ${ }^{29}$ a political and cultural cluster of regions with their local elites under the suzerainty of the Parthian king. ${ }^{30}$ In this situation, the balance of power between various local geopolitical entities themselves could also become an issue depending on the macro- and micropolitical constellation. ${ }^{31}$ Local shifts of influence became most tangible for Gordyene and Sophene in the 1st century BCE due to the political rise of two important transregional players-Greater Armenia and Adiabene. ${ }^{32}$ As far as Greater Armenia is concerned, the conquests of the Armenian King Tigranes II (known as the Great), who started his reign only as a vassal of the Parthian king, Mithradates II, put an end to the Hellenistic kingdom of Sophene, which was most likely directly absorbed in ca. 95 BCE into Tigranes II's recently expanded kingdom of Greater Armenia. ${ }^{33}$ After 66 BCE (marking the end of the era of Tigranes II's conquests), the area once occupied by the Hellenistic kingdom of Sophene disintegrated into several smaller countries and their local elites never again managed to obtain royal status (it must be noted in this context that the royal investitures of Tigranes the Younger in $66 \mathrm{BCE}$ and Sohaemus in $54 \mathrm{CE}$ came from Rome and were ephemeral). ${ }^{34}$ a similar fate was shared by Gordyene ${ }^{35}$ - Tigranes II eliminated its King Zarbienos in ca. 71/70 BCE and directly took over the territory of Gordyene, which still remained part of Armenia even after the Romans defeated Tigranes II and dismantled his expanded kingdom. ${ }^{36}$ In the late 1 st century BCE, Gordyene was subdued by Adiabene until at least $115 \mathrm{CE}$, but possibly as long as until $298 \mathrm{CE} .{ }^{37}$ Indeed, Adiabene reached

25 De Callataÿ 1996; Grabowski 2011; Marciak - Wójcikowski 2016.

26 Marciak 2017, 422-423.

27 Marciak 2017, 422-423.

28 Marciak 2017, 423-424.

29 For the term, see de Jong 2013.

30 See Marciak 2017, 425-426.

31 Marciak 2017, 426.

32 See Marciak 2017, 128-136, 243-254, 426-427.

33 Marciak 2017, 426.

34 See Marciak 2017, 128-136, 426-427.

35 See Marciak 2017, 243-254, 426-427.

36 Marciak 2017, 426.

37 Marciak 2017, 426. 
the peak of its political importance in the 1 st and 2 nd centuries CE. ${ }^{38}$ At that time, Adiabene controlled not only Gordyene, but also the rest of the Mesopotamian valley as far as Nisibis. ${ }^{39}$

In Parthian and Sasanian times, we hear of many more local geopolitical entities in the Upper Tigris area. ${ }^{40}$ In the northwestern part of the Upper Tigris area, we hear of Little Sophene, also known as Sophene Šahuni (including only the modern Dersim and the lower Murat Valley); Anzitene, centered on the Kharput plain; Ingilene, around Eğil; Asthianene (in the Bingöl plain); Balabitene (in the plain around the city of Palu); Sophanene, between the Dibene and Batman rivers; and Arzanene, east of the Batman River. All of these countries emerged in the territories once belonging to the Hellenistic kingdom of Sophene. On the one hand, it seems that they all had their own distinctive ethnic and cultural features: Ammianus Marcellinus (Amm. Mar. 18.9.2) and the Byzantine legislation (Corpus Iuris Civilis, especially Cod. Iust. 1.29.5 and Leg. Nov. 31.1.3) explicitly use the term ethne/gentes with regard to these countries. ${ }^{41}$ They all also had local noble families holding hereditary power in their lands, as is indicated by the Byzantine and Armenian sources. ${ }^{42}$ On the other hand, all of these countries are occasionally called Sophene in Armenian ( $C o p^{~} k$ '), and this name is used as a synonym for Armenia Quarta (Movsēs Xorenac 'i 2.8; Geography of Ananias of Širak 5.22.2). ${ }^{43}$ Likewise, the Roman name of one of the specific regions located between the Dibene and Batman rivers bears a very telling name-Sophanene-which is likely coined after the Semitic version of the heartland's name, Sophene. ${ }^{44}$ All of this testifies to the close political and cultural ties of this area that once belonged to the kingdom of Sophene and suggests that despite all the ethnic or cultural differences between them, there was still some common base connecting them all.

East of Arzanene, we hear of several other minor countries from $298 \mathrm{CE}$ on-Moxoena (the mountainous region south of Lake Van and north of the Bohtan River), Rehimena (perhaps matching the valley stretching from the modern Eskieruh towards the Bohtan River), and Zabdicena (around Bezabde), all of which most likely developed as regions once belonging to Gordyene. ${ }^{45}$ Further to the south, an important country became established in Osrhoene, approximately around Edessa. ${ }^{46}$ Osrhoene certainly profited from its strategic location as a water-supply stopping point close to major west-east and north-south routes crossing the Euphrates and the Syrian Khabur region. Founded as a Hellenistic foundation by Seleucus I Nicator, it transformed and emerged as a kingdom ruled by the Abgar dynasty in the late 2nd century BCE. Osrhoene's culture, despite some Hellenization and Romanization of its elites, featured undeniable affinities with the surrounding Semitic cultures of the Near East, including a great deal of Arab influence.

38 Marciak 2017, 426.

39 Marciak 2017, 426-427.

40 See Marciak 2017, 17-23.

41 Marciak 2017, 55.

42 Marciak 2017, 55.

43 Marciak 2017, 55.

44 Adontz - Garsoïan 1970, 33-34; Marciak 2017, 77-78.

45 See Marciak 2017, 187-196.

46 See Lieu 1997; Ross 2001. 
In this part of Mesopotamia and further east towards Adiabene and Hatra, we occasionally hear of many more small geopolitical entities and people: especially Anthemousia around Batnae, Carrhae, Rhesaina, Singara, and various Arab tribes. ${ }^{47}$ The geopolitical fragmentation of this part of Mesopotamia in the times of Emperor Trajan has been aptly labeled as "the political jungle: a patchwork of different ethnicities, modes of production and models of social organization." 48

These small countries in the Upper Tigris area were usually geographically distinctive, and consequently their existence as geopolitical entities with their own local elites may have been much older than their first attestation in ancient sources. ${ }^{49}$ In fact, their first appearance in ancient sources can be seen as the result of greater political emancipation, which was in turn subject to frequently changeable geopolitical conditions. These changes were affected not only by the conflict of neighboring great powers, being conditioned by Parthian and early Sasanian modes of control of their vast imperial territory, but were also influenced by mutual competition between smaller local chiefdoms and kingdoms. ${ }^{50}$

From the 1st century BCE onwards, the area of northern Mesopotamia and Armenia became the scene of competition between Rome and the Parthians/Arsacids (the latter were replaced by the Sasanians in the early 3rd century CE). ${ }^{51}$ The area of the Upper Tigris was strategically significant as a transit region located on the crossroads of important long-distance communication lines between Cappadocia, Greater Armenia, Media, and Babylonia: the Tomisa crossing of the Euphrates River, the Ergani pass in the Taurus Mountains, the Bitlis pass leading over the Taurus to Greater Armenia, important crossing points of the Tigris River in Gordyene and Adiabene (Cizre, Feshkhabur, Abu Dhahir, Abu Wajnam, Eski Mosul, and Nineveh), a route along the east bank of the Tigris to Babylonia, and the Keli-Shin pass in the Zagros leading to Media. ${ }^{52}$ Likewise, natural resources of the Upper Tigris area were undoubtedly important to the neighboring superpowers (e.g., agricultural produce, timber, and copper ore or ingots).

There is no question that over the course of time Rome prevailed in military and political competition in northern Mesopotamia. ${ }^{53}$ By 64 BCE, Pompey could freely decide about the political status of Sophene, and the same was possible for Emperor Nero on the eve of the Roman invasion in Armenia in $63 \mathrm{CE}^{54}$ The political status of the territory once belonging to the Hellenistic kingdom of Sophene until the end of the 3rd century CE is not entirely clear (because of the lack of sources), and the political situation may have been changeable. ${ }^{55}$ Nevertheless, even indirect political control of the Roman Empire over Sophene is very likely to have occurred, since this area was strategically crucial to the Romans for controlling access to Mesopotamia and Arme-

47 See Marciak 2017, 382-392.

48 Sommer 2013, 14.

49 See Comfort - Marciak 2018, 13-14.

50 See Comfort - Marciak 2018, 14.

51 See Marciak 2017, 104-107.

52 Marciak 2017, 429.

53 See Marciak 2017, 128-154, 246-254, 366-409, 429-430.

54 Marciak 2017, 429.

55 Marciak 2017, 429. 
nia. ${ }^{56}$ In Mesopotamia, a turning point came with Lucius Verus' Eastern campaigns in 163-166 CE when Osrhoene became a Roman client kingdom and the Romans kept garrisons in several Mesopotamian cities, especially in Nisibis. ${ }^{57}$ This was followed by the creation of the Roman province of Osrhoene by Septimius Severus in 195 CE and then the creation of the province of Mesopotamia. ${ }^{58}$ Finally, in $298 \mathrm{CE}$ the territories to the north of Osrhoene and Mesopotamia - that is, Sophene, Anzitene, Ingilene, and Sophanene (regiones Transtigritanae) — were ceded by the Sasanians to the Roman Empire. From then on, they officially belonged to the Roman sphere of influence (the same was at first true for Arzanene and Gordyene, but they were regained by the Sasanians in $363 \mathrm{CE}) .{ }^{59}$ The border set up in $363 \mathrm{CE}$ between the Romans and the Sasanians along the line approximately marked by the courses of the Batman and Syrian Khabur rivers in Mesopotamia remained fairly stable for the next two centuries. However, the regiones Transtigritanae did not immediately become Roman provinces, but first functioned as semi-autonomous Roman principalities until the first half of the 6th century CE, when they were absorbed into the provincial structure of the Byzantine kingdom (to a limited extent in $527 \mathrm{CE}$, and fully in $536 \mathrm{CE}$ ). ${ }^{60}$ a much different story was written for Gordyene and Adiabene - after $363 \mathrm{CE}$, Gordyene returned to the Sasanians, but not as part of Adiabene; instead, it became part of the newly formed province of Arbāyestān (Beth 'Arbāyē), which comprised the territory conquered from the Byzantine kingdom. ${ }^{61}$ In turn, in northern Mesopotamia the Roman expansion gradually limited Adiabene's political presence on the west bank of the Tigris. ${ }^{62}$ However, it should be stressed that despite the fact that Adiabene was affected by several Roman campaigns (Trajan in 115-116 CE, Septimius Severus in 195 CE, Caracalla in 216 CE, Galerius in 298 CE, Constantius II in $343 \mathrm{CE}$, Arethas in $541 \mathrm{CE}$, Khusro II in $590 \mathrm{CE}$, and Heraclius in $627 \mathrm{CE}$ ), a long-term occupation or incorporation of Adiabene's core territory (located east of the Tigris) is not really attested in ancient sources. ${ }^{63}$ Thus, Adiabene always remained an integral part of the Parthian and Sasanian kingdoms.

The complicated political history of the Upper Tigris area translated directly into an ambiguous record of its cultural affinities.

The case of Sophene's material culture is most ambiguous. ${ }^{64}$ The Hellenistic kingdom was founded by one of the lines of the Orontid dynasty. Furthermore, much historical data points to Armenian influence in this region. Accordingly, many scholars have traditionally perceived Sophene as an integral and important part of the Armenian world. ${ }^{65}$ Some important Greek and Roman ethnogeographers (e.g., Strabo 11.12.3-4; Pliny the Elder, HN 6.22; Ptolemy 5.13.13) saw Sophene as a distinctive part of Greater

\footnotetext{
Marciak 2017, 429.

Marciak 2017, 181.

Marciak 2017, 385-392.

Marciak 2017, 429.

Marciak 2017, 429.

Marciak 2017, 254.

Marciak 2017, 417-418.

Marciak 2017, 418.

See Marciak 2017, 56-112.

65 Marciak 2017, 111.
} 
Armenia. ${ }^{66}$ Likewise, in the 6th century CE both Procopius (Aed. 3.1.17-27) and the Byzantine administrative sources (Cod. Iust. 1.29.5 and Leg. Nov. 31.1.3) perceived this region as a distinctive kind of Armenia in cultural, ethnic, administrative, and political terms ${ }^{67}$ As a result, it is not surprising that later Armenian sources (especially the Epic Histories) that write the Pan-Armenian history also describe the nobility in this region as members of the Armenian commonwealth both in political and religious terms. ${ }^{68}$ There is also a considerable amount of data pointing to Iranian cultural influence (sometimes Armenian-Iranian), though it concerns mainly Sophene's elites (onomastic data, social and political institutions) and religion (both historical and archaeological data). ${ }^{69}$

At the same time, there is a lot of historical data suggesting a local and non-Armenian character. First, in reporting a well-known Siedlungslegende about Armenos and his compatriots (Geog. 11.14.12), Strabo implies that the people who previously inhabited this area (which he called the Sopheni) were not Armenian in origin. ${ }^{70}$ Indeed, most of the local toponyms, even if recorded in later Armenian sources, turn out to be pre- and non-Armenian in origin. ${ }^{71}$ Likewise, Plutarch's description of the positive reaction of Sophene's population towards Roman troops against Tigranes the Great (Luc. 24.8) is certainly surprising, if one should still be inclined to see Tigranes the Great's actions as an attempt to unify one people under one ruler.

Indeed, there is also some data showing Sophene's connection with the Mesopotamian environment-Pliny the Elder (HN 5.66) sees Sophene as part of Syria, while Laterculus Polemii Silvii (93) sees it as part of Oriens (together with Mesopotamia, Euphratensia, and Osrhoene), and both Procopius (Aed. 3.2.1) and the Descriptio Orbis Romani (909-965) describe it as part of Mesopotamia (though they also interchangeably use the name Armenia). ${ }^{72}$ Indeed, the Papyri Euphratenses testify to Sophene's close commercial ties with the Syrian-Khabur area, ${ }^{73}$ and likewise, the ecclesiastical organization in Sophene had a distinct structure from that in Greater Armenia and was subject to the Patriarch of Constantinople through its metropolitan location at Amida rather than the Armenian Catholicos at Dvin. ${ }^{74}$

Importantly, Greek-Hellenistic culture made a strong mark on Sophene's material culture, particularly concerning economic levels. ${ }^{75}$ a considerable number of artefacts (including everyday objects) from this background are attested in the archaeological excavations, both in the urban and rural environment (coins, pottery, domestic and military architecture, and masonry). ${ }^{76}$ The Hellenistic period also generated a popularity for the use of Greek language and script (including personal names). ${ }^{77}$ In turn, the Roman

\footnotetext{
Marciak 2017, 111.

Marciak 2017, 111.

Marciak 2017, 111-112.

9 Marciak 2017, 111.

Marciak 2017, 111.

See Marciak 2017, 77-80.

Marciak 2017, 61.

3 Marciak 2017, 64-65.

4 Marciak 2017, 62-64.

5 Marciak 2017, 112.

76 Marciak 2017, 112.

77 Marciak 2017, 112.
} 
cultural influence (clearly resulting from Rome's political control) brought intensive urbanization and militarization, as the region became covered with a network of Roman roads, bridges, forts, and fortified cities. ${ }^{78}$

In turn, our knowledge on Gordyene's material culture is very limited. ${ }^{79}$ However, recent archaeological surveys offer preliminary data on the material culture in this area in the late Iron Age, pointing to a sudden break in the presence of regional pottery after the 9th century BCE and the beginning of a new distinctive local pottery before the end of the 5th century BCE. ${ }^{80}$ This turns out to be in surprising agreement with the picture of Gordyene gained from Xenophon as a cultural and political enclave with a highly distinctive local character. Otherwise, the slight archaeological record suggests that Gordyene came under some of the common cultural influences in the Near East, including Greek-Hellenistic and Roman cultures, which particularly made their mark on its military urbanization and communication network. ${ }^{81}$ Finally, it should be stressed that in Late Antiquity, Gordyene became the scene of the thriving monastic life of Syriac Christianity, which is definitely in agreement with its probably primarily Semitic origin. ${ }^{82}$

Adiabene should be perceived in cultural terms as a country with primarily local Semitic traditions that with time also became subject to common cultural influences in the Near East: Greek-Hellenistic and Iranian cultures. ${ }^{83}$ Greek-Hellenistic culture expanded in the region from the 3rd century BCE, while the presence of Iranian influence began to become more tangible in the region from the second half of the 2nd century BCE ${ }^{84}$ Iranian culture (first in Parthian and next in Sasanian manifestations) appears to have had a powerful impact on this region from the 1st century BCE onwards, but Greek-Hellenistic culture also considerably influenced this primarily Semitic region, which is still visible in the archaeological data until at least the 2 nd century CE ${ }^{85}$ In contrast, short phases of military occupation by the Roman legions (under emperors Trajan and Septimius Severus in particular) did not make any important mark on its cultural affinities (and, not surprisingly, findings of Roman Eastern sigillata have been extremely rare among archaeological teams working in the Zakho and Dohuk areas in recent years). ${ }^{86}$

In summary, the study of the history and culture of small geopolitical entities in the Upper Tigris region can be a fascinating but confusing journey. These countries appear to have had local origins, but were also exposed to challenges in world history. The result is that their political affiliation and cultural character, be it Armenian, Parthian-Sasanian, or Roman, frequently escapes any comprehensive labeling by modern historians.

\footnotetext{
78 Marciak 2017, 112.

79 See Marciak 2017, 204-240.

80 Marciak 2017, 229.

81 Marciak 2017, 254.

82 Marciak 2017, 217.

83 See Marciak 2017, 272-343.

${ }^{84}$ Marciak 2017, 342.

85 Marciak 2017, 342.

86 Marciak 2017, 343.
} 


\section{BIBLIOGRAPHY}

Adontz, N., Garsoïan, N.G. (1970), Armenia in the Period of Justinian: The Political Conditions Based on the "Naxarar" System, translated with partial revisions, a bibliographical note and appendices by N. G. Garsoïan, Lisboa.

Bedoukian, P. Z. (1978), Coinage of the Artaxiads of Armenia, London.

Callataÿ, F. de (1996), Abdissarès L'Adiabénien, Iraq 58: 135-145.

Comfort, A., Marciak, M. (2018), How Did the Persian King of Kings Get his Wine? The upper Tigris in Antiquity (c. 700 BCE to 636 CE), Oxford.

Facella, M. (2006), La dinastia degli Orontidi nella Commagene ellenistico-romana, Pisa.

Garsoïan, N. G. (1997), The Emergence of Armenia, in: R. G. Hovannisian (ed.), The Armenian People from Ancient to Modern Times, vol. 1: The Dynastic Periods: From Antiquity to the Fourteenth Century, New York: 37-62.

Grabowski, M. (2011), Abdissares of Adiabene and the Batas-Herir Relief, Światowit: Annual of the Institute of Archaeology of the University of Warsaw 9: 117-140.

Jong, A. de (2013), Hatra and the Parthian Commonwealth, in: L. Dirven (ed.), Hatra: Politics, Culture and Religion between Parthia and Rome, Stuttgart: 143-160.

Lieu, S. (1997), Edessa, EI 8: 174-175.

Marciak, M. (2017), Sophene, Gordyene, and Adiabene: Three Regna Minora of Northern Mesopotamia between East and West, Leiden-Boston.

Marciak, M., Wójcikowski, R. (2016), Images of Kings of Adiabene: Numismatic and Sculptural Evidence, $\operatorname{Iraq} 78:$ 1-23.

Ross, S. K. (2001), Roman Edessa: Politics and Culture on the Eastern Fringes of the Roman Empire, 114-242 CE, London.

Sommer, M. (2013), In the Twilight: Hatra between Rome and Iran, in: L. Dirven (ed.), Hatra: Politics, Culture and Religion between Parthia and Rome, Stuttgart: 33-44. 